\title{
RELIGIONSPSYKOLOGI SOM TEORI OM DEN INDIVIDUELLE RELIGIØSITET
}

\author{
Problemer, positioner og perspektiver
}

\author{
Af Troels Nørager
}

Religionspsykologiens arbejdsområde er studiet af individets og gruppens religiøsitet, sådan som denne kommer til udtryk i oplevelser, trosforestillinger, holdninger og adfærd. Bag denne brede, overordnede karakteristik skjuler der sig imidlertid en række principielle, metodiske problemer, som det er formålet med denne artikels første del (afsnit 1-2) at belyse lidt nærmere.

Kombinationen af en introducerende oversigt og en statusopgørelse og det er faktisk, hvad der er denne korte afhandlings intention - ville dog være både énsidig og uretfærdig, om den indsnævrede sit perspektiv til en omtale af religionspsykologiens problemer. Trods alt er religionspsykologien jo først og fremmest en konkret forskningsaktivitet, som i årenes $1 \varnothing \mathrm{b}$ har materialiseret sig i et utal af monografier og afhandlinger. Med andre ord: Religionspsykologien har frembragt en lang række resultater (teorier, indsigter, empirisk materiale), og som al anden forskning har den et rimeligt krav på at blive bedømt på sine gerninger.

Inden for denne artikels rammer kan der naturligvis kun blive tale om at behandle en meget begrænset del af disse resultater, og jeg har derfor valgt at betragte religionspsykologiens udvikling som forskellige udformninger af en teori om den individuelle religiøsitet. For denne begrænsning af perspektivet til en kort karakteristik af centrale positioner, taler dog også en anden omstændighed: Når det som her drejer sig om at gøre status over en videnskabelig disciplins analytiske kapaciteter og potentialer, bør man retfærdigvis teste den på det område, hvor den i følge sin egen selvforståelse er stærkest, og det er netop som afdækningen af, hvad der i den engelsksprogede litteratur sammenfattes som »religious experience«. I artiklens hoveddel (afsnit 3-6) vil formålet derfor være at behandle nogle af de ansatser til en systematisk religionspsykologi, som har spillet en hovedrolle i disciplinens snart 100-årige levetid. 


\section{Religionspsykologi som teori}

En statusopgørelse er dog ikke færdig, når materialet er gennemgået. Den rejser spørgsmål og rummer perspektiver, som jeg i artiklens afsluttende del (afsnit 7-9) vil knytte nogle mere personlige vurderinger og kommentarer til.

\section{Psykologiens etablering som selvstændig videnskab}

Interessen i at forstå menneskets »sjæl« med henblik på at kunne helbrede, eller måske snarere kontrollere den, er formentlig lige så gammel som kulturen. I hvert fald er den i den vesterlandske civilisation en uadskillelig del af kirkehistorien, og "psykologi«, forstået som denne optagethed af menneskets indre liv, kan derfor med fordel studeres i et bredere, mentalitetshistorisk perspektiv.

Det er imidlertid tankevækkende, at selve betegnelsen psychologia dukker op i 1500-tallet som led i renæssancehumanismens bestræbelse på at etablere en af kirkelæren uafhængig videnskab om mennesket, en anthropologia. Senere, i 1700-tallet, møder vi hos filosoffen Christian Wolff distinktionen mellem henholdsvis »rationel« og »empirisk« psykologi, som bl.a. Kant viderefører. ${ }^{1}$ Denne modstilling er vigtig, dels fordi den identificerer to traditioner, der stadig spiller en rolle, dels fordi den signalerer en hel række metodisk-videnskabsteoretiske dilemmaer, der er psykologien iboende. Psykologier af den rationelle, filosofiske type, der har rødder tilbage i thomistisk filosofi, har som regel haft plads til Gud, hvorimod den »empiriske « psykologi er decideret anti-metafysisk og anti-spekulativ. ${ }^{2}$

Af afgørende betydning for forståelsen af moderne psykologi og religionspsykologi bliver det derfor, at psykologiens etablering som selvstændig videnskab sker i forlængelse af den empiriske psykologis traditionslinie. For det første implicerer det, at den moderne psykologi er kendetegnet ved sin kritisk-polemiske front imod enhver form for filosofisk og/eller metafysisk spekulation. For det andet bliver resultatet, at psykologien forstår sig selv som en eksperimentel videnskab med naturvidenskaberne som forbillede. Konkret: »sjælen« forsvinder, og spørgsmålet om, hvad der træder i stedet, hører ikke til de dummeste, man kan stille psykologien. ${ }^{3}$

I første omgang bliver svaret, at psykologiens genstand forstås som associationer og perceptioner, der udsættes for diverse eksperimentelle undersøgelser. Dette er f. eks. tilfældet hos Wilhelm Wundt, der i 1873 oprettede det første psykologiske laboratorium i Leipzig. Betegnelsen »laboratorium« er sigende: Man ser for sig billedet af hvidkitlede psyko- 


\section{Troels Nørager}

loger, der via eksperimenter forsøger at afdække det psykiske livs lovmæssigheder. I denne forbindelse bør det også tilføjes, at Freud langt fra var den eneste, hvis vej til psykologien gik fra den eksperimentelle fysiologi.

Det er naturligvis ikke muligt her at gå ind i en mere udførlig behandling af de mange spændende aspekter af psykologiens videnskabshistorie; jeg vil derfor blot hæfte mig ved en enkelt omstændighed, som til gengæld er central: Psykologien har altid haft vanskeligt ved at definere sit forskningsobjekt og derfor også været $i$ vildrede med, hvad der var den mest adækvate indfaldsvinkel. Som allerede antydet interesserer man sig i første omgang for associationer og perceptioner, og heri ligger implicit et begreb om psykologi som studiet af mental aktivitet, forstået som bevidsthedsakter. Imidlertid blev det efterhånden klart, at man med associationspsykologien havde arvet en række »tunge« filosofiske problemer med rødder tilbage til Hume, og dermed er dilemmaet der igen: Hvis psykologien hælder for stærkt til en naturvidenskabelig selvforståelse, kan den åbenbart ikke selv forstå, hvad det er, den foretager sig, og hvis den omvendt bliver for filosofisk-spekulativ, truer den respektable, »wissenschaftliche« facade straks med at krakelere. ${ }^{4}$

Det er ikke mindst på baggrund af dette dilemma, man må forstå den radikale løsning, som lanceres af John B. Watson og senere af B. F. Skinner: Hvis psykologien skal være videnskabelig, må den koncentrere sig om studiet af den ydre, iagttagelige adfoerd og overlade »det indre filosofisk-metafysiske spekulations klamme favntag. Behaviorismen dominerede psykologien i perioden fra ca. 1930-60, hvor der - ganske tankevækkende - stort set ikke blev forsket i religionspsykologi. Konsulterer man imidlertid en moderne håndbog i psykologi, vil man møde et forsøg på - i selve definitionen af psykologiens genstand - at tage højde for både »det indre« og »det ydre«:

For our purposes, we will define psychology as the science that studies behavior and mental processes. This definition reflects psychology's concern with an objective study of observable behavior and still recognizes the importance of understanding mental processes that cannot be directly observed but must be inferred from behavioral and physiological data. 5

Citatet ser pænt og uskyldigt ud, men kan dog ikke skjule den kendsgerning, at den psykologiske videnskab står over for to alvorlige problemer: 1) forholdet mellem det indre og det ydre; 2) forholdet mellem det fysiologiske og det psykologiske, der jo i realiteten er en afspejling af filosofiens gamle sjæl/legeme-problem. 


\section{Religionspsykologi som teori}

\section{Og hvad er så "religionspsykologi« for en størrelse?}

Det ligger i selve betegnelsen "religionspsykologi «, at der er tale om en forskningsretning, som i en eller anden forstand baserer sig på moderne psykologi. Bag denne bevidst upræcise formulering skjuler sig den kendsgerning, at religionspsykologien har tiltrukket forskere med meget forskellig baggrund og dermed også stærkt varierende erkendelsesinteresser. Den videnskabelige psykologi har traditionelt givet den religiøse dimension en særdeles stedmoderlig behandling, hvilket næppe kan overraske på baggrund af, hvad der er sagt i det foregående. ${ }^{6}$

I praksis er religionspsykologerne derfor hovedsagelig blevet rekrutteret fra religionsvidenskabens og teologiens rækker; efterhånden er det dog ikke ualmindeligt at støde på religionspsykologer med en akademisk grad i både psykologi og religionsvidenskab/teologi, og en sådan kombination må naturligvis principielt anses for den ideelle. Imidlertid er problemet altså, at det ikke på forhånd er let at sige, hvad en religionspsykolog og dennes religionspsykologi er for noget. Forskellene i bagved liggende motivationer og erkendelsesinteresser viser sig bl.a. i en meget forskellig brug af psykologiske indsigter og metoder, og heri ligger en stor del af forklaringen på, at den konkrete forskning opviser et bredt (nogle ville sige: foruroligende bredt) spektrum, der strækker sig fra empirisk-eksperimentelle undersøgelser, ofte bearbejdet med avanceret statistik, til mere teoretisk-metodologiske studier.

Stort set hersker der dog enighed om, at religionspsykologien,såfremt den vil være en videnskabelig disciplin, må forpligte sig på en empirisk og objektiv tilgang. Alle påberåber sig da også empirien (og dermed den implicitte læggen afstand til en spekulativ-metafysisk religionspsykologi), men de opfatter den og forholder sig til den på meget forskellig måde. Hvad »objektiviteten « angår, fortolkes dette problem generelt på den måde, at religionspsykologien må sætte parentes om ethvert spørgsmål, der vedrører religiøsitetens iboende sandhed eller gyldighed. Konkret implicerer det, at rapporter om religiøse oplevelser tages for pålydende som psykiske realiteter, men altså uden at man går ind på spørgsmålet om deres ontologisk-metafysiske status.

Sammenfattende sagt: Når religionspsykologien i metodisk-videnskabsteoretisk henseende er et særligt problemfyldt interesseområde, skyldes det især følgende omstændigheder:

1) Den har svært ved at fastlægge sit genstandsfelt. Dette problem er til 


\section{Troels Nørager}

dels en arv fra psykologien, men hertil kommer de kendte vanskeligheder med hensyn til at definere begreber som 'religion' og 'religiøsitet'.

2) Sammenlignet med religionssociologien er religionspsykologien på mindst to punkter i en mere vanskelig situation: a) Hvor religionssociologien er en integreret del af sociologien (jf. Weber og Durkheim), er religionspsykologien blevet betragtet med betydelig skepsis og dermed stort set forsømt af den almene psykologi. Ganske vist spiller problemet 'religion' en central rolle hos Freud og Jung, men de udgør i denne henseende undtagelser $i$ det generelle billede. ${ }^{7}$ b) Ved sin henvisthed til det religiøse individ kommer religionspsykologien - atter sammenlignet med religionssociologien - $\mathrm{i}$ berøring med problemstillinger, som er egnede til at bringe en »videnskabelig« disciplins selvforståelse i fare; den får nemlig svært ved at undgå spørgsmål, der traditionelt (og måske af gode grunde?) behandles i religionsfilosofien og den filosofiske antropologi.

Stillet over for dette omfang af interne problemer gør man formentlig bedst $\mathrm{i}$ at interessere sig for, hvad religionspsykologerne de facto arbejder med, og hvilke resultater de er nået frem til. Det er imidlertid lettere sagt end gjort, fordi fællestemaet »religious experience « i praksis oftest studeres som ét af flere delaspekter: omvendelse, mystik, bøn, tungetale - for nu blot at nævne nogle af de klassiske temaer.

I et historisk perspektiv kan man konstatere, at en tiltagende tematisk specialisering er gået hånd $\mathrm{i}$ hånd med en tendens til at tilnærme religionspsykologien til religionssociologiske og socialpsykologiske problemer og indfaldsvinkler. Fordelen ved denne udvikling har været, at religionspsykologien metodisk har fået fastere grund under fødderne, men ulempen har været, at man har fjernet sig tilsvarende fra det oprindelige projekt: udforskningen af den individuelle religiøsitet.

I realiteten gemmer der sig bag denne udvikling et grundlæggende valg: Skal religionspsykologien »blot« tage sig af de psykologiske rester, som religionssociologien efterlader, eller har den derudover den mere systematiske opgave at arbejde henimod en teori om den individuelle religiøsitet? Som allerede titlen på denne artikel røber, er jeg personligt tilhænger af den sidstnævnte mulighed, men et sådant synspunkt bør begrundes lidt nærmere.

Jeg er naturligvis tilhænger af et nært samarbejde imellem religionsvidenskabens forskellige discipliner, men tværfaglighed kan blive farlig, hvis 'den giver anledning til, at de enkelte bidragydere »glemmer«, hvad 


\section{Religionspsykologi som teori}

det er, de hver især har at bidrage med. Det må netop være i religionsvidenskabens (og teologiens) interesse, at religionspsykologien fastholdes på den opgave, som den - i det mindste i følge sin oprindelige selvforståelse - er til for, nemlig at udforske individets (og gruppens) religiøsitet. Dermed være ikke sagt, at mere begrænsede, empiriske undersøgelser ikke er både nødvendige og værdifulde, med de må på en eller anden måde selv pege henimod eller kunne sættes i relation til mere generelle problemstillinger.

I det følgende er det mit mål at forfølge en sådan mere systematisk, men samtidig begrænset problemstilling, idet jeg stiller en række spørgsmål til de historisk set vigtigste teori-dannelser:

1) Hvad er det for et begreb om 'religion'/'religiøsitet', der implicit eller eksplicit opereres med?

2) Hvorfra hentes de data, der søges fortolket psykologisk?

3) Hvilken indfaldsvinkel og metode anvendes?

4) Hvad bliver resultatet med hensyn til en mere overordnet teori om, hvad der grundlæggende kendetegner den religiøse oplevelse, respektive den individuelle religiøsitet?

Disse spørgsmål skal nu i oversigtlig form søges belyst i forhold til fire nogenlunde klart definérbare positioner, hvoraf de to første kan siges at udgøre den »klassiske« religionspsykologi, mens de to sidste har spillet en hovedrolle i moderne religionspsykologi siden tresserne.

\section{William James' klassiske ansats}

William James' (1842-1910) Gifford Lectures (1901-02), der senere blev udgivet under titlen The Varieties of Religious Experience og siden er blevet trykt i utallige oplag, indtager en ubestridt placering som religionspsykologiens klassiker par excellence. Forklaringen herpå må søges i forfatterens sjældne evne til at forene en levende interesse for det religiøse livs udtryksformer med en uhildet og fordomsfri betragtning. Bogens undertitel, »A Study In Human Nature «, må også ses i dette perspektiv: Ved at lade de religiøse fænomener komme til orde på deres egne præmisser tilbydes læseren et fascinerende indblik i menneskehjertets forunderlige fænomenologi.

Ved »religion « forstår James »the feelings, acts, and experiences of individual men in their solitude, so far as they apprehend themselves to stand in relation to whatever they may consider the divine ${ }^{8}$ Der er tale om en 


\section{Troels Nørager}

»substantiel« (modsat »funktionel«) religionsdefinition, ${ }^{9}$ hvor især tre ting falder i øjnene: a) James demonstrerer et klart blik for, at »religiøsitet« er noget, der omfatter hele personligheden («feelings, acts, and experiences«); b) definitionen hævder implicit, at man bedst får fat på religiøsitetens væsen, hvis man koncentrerer sig om de situationer, hvor den enkelte er alene med det guddommelige; c) endelig ligger der bag formuleringen whatever they may consider the divine« ikke blot en erkendelse af, at religion kan være mangt og meget, men også den grundopfattelse, at ligesom det kun er den virkeligt musikalske, der kan udtale sig om, hvordan musik opleves, således må tilsvarende afgørelsen af, hvad religion »er«, overlades til de mennesker, James kalder for "religiøse virtuoser«.

Hermed har jeg allerede antydet, hvorfra James henter sit materiale; i direkte forlængelse af definitionen fokuserer han på de såkaldte »human documents«, altså breve, dagbøger, biografier, beskrivelser i opbyggelseslitteratur og lignende. På denne måde tilvejebringes et omfattende materiale, der gør det muligt at behandle en række klassiske religionspsykologiske temaer så som: forskellige måder at være religiøs på, omvendelse, mystik, etc.

Som en følge af forkærligheden for de religiøse virtuoser har man kaldt James' indfaldsvinkel for »de ekstreme tilfældes metode«; og det siger sig selv, at det heri indeholdte valg kan kritiseres, men man må under alle omstændigheder indrømme, at metoden har frembragt et materiale, som bliver ved med at fascinere og inspirere. I dette materiale afdækker James så analoge strukturer og tilbagevendende fænomener, som søges fortolket ud fra samtidens psykologiske viden, der også indbefatter en hensyntagen til underbevidste processer.

Resultatet af disse afgørelser viser, at James' teori om den individuelle religiøsitet er farvet af tidens interesse for omvendelsen som det fænomen, der bedst var i stand til at åbenbare religiøsitetens væsen. I den »egentlige« religiøse oplevelse sker der i følge James det, at tanker og følelser, der $i$ længere tid har ligget latent $i$ underbevidstheden, gradvist eller pludseligt bryder igennem. Den enkelte oplever dette på den måde, at »det delte selv« (James: »the divided self «), der er plaget af følelsen af at være »forkert « (uværdig, syndig), transformeres til en harmonisk énhed (James: »unification«), hvorved der skabes fred i sindet. 


\section{Religionspsykologi som teori}

\section{Den eksperimentelle religionspsykologi}

Hvor den tidlige, amerikanske religionspsykologi går til værks på en måde, der er influeret af den filosofiske pragmatisme, udvikles i Tyskland en særegen form for religionspsykologi, hvis selvforståelse er bestemt af den etablerede psykologis dengang dominerende metode: den eksperimentelle. Den eksperimentelle psykologis mål var - via kontrollérbare eksperimenter - at nå frem til sikker og eksakt viden om mentale processer.

Karl Girgensohn (1875-1925), stifteren af denne religionspsykologiske retning, er i metodisk henseende afhængig af Oswald Külpe, som i et fors $\emptyset \mathrm{g}$ på at overvinde begrænsningerne $\mathrm{i}$ Wundts psykologi oprettede den såkaldte Würzburg-skole, hvor man var optaget af at gøre også de »højere, sjælelige funktioner « (tænkning, følen, vurderen) til genstand for eksperimentelle forsøg. For teologen Girgensohn såvel som for to af hans ligeledes teologiske elever, Werner Gruehn (1887-1961) og vores egen Villiam Grønbæk (1897-1970), var der hermed tilsyneladende skabt mulighed for at gøre religiøse oplevelser til genstand for en strengt videnskabelig udforskning. ${ }^{10}$

Den eksperimentelle religionspsykolog ser sig selv som »forsøgslederen«, der med det psykologiske laboratorium som garant for videnskabeligheden udsætter en række forsøgspersoner for diverse stimuli med henblik på en eksakt registrering af personernes reaktion. Det kan være vanskeligt at forestille sig, hvordan der kan komme religionspsykologisk interessante iagttagelser ud af en fremgangsmåde, som er egnet til at lede tankerne i retning af Pavlovs hunde, men til beroligelse for nogle og forargelse for andre kan oplyses, at forsøgspersonerne er teologiske studenter og de anvendte stimuli ord og sætninger hentet fra den kristne opbyggelseslitteratur.

Det paradoksale i denne fremgangsmåde ligger naturligvis i den selvmodsigende dobbelthed af eksperimentel metode som middel og introspektion som mål, og på den nutidige læser virker det mildt sagt forbløffende, at de eksperimentelle religionspsykologer var i stand til naivt at overse de mange subjektive og tilfældige momenter, der i realiteten var forbundet med forsøgene.

Der er altså kort sagt rig anledning til at gøre sig lystig over den eksperimentelle religionspsykologis metode såvel som af dens tilbøjelighed til under hånden at sætte »religion « lig med kristen fromhed. Når man i dag studerer de såkaldte "protokoller« (dvs. forsøgspersonernes verbaliserede 
associationer på de anvendte forsøgsord eller -sætninger), har man dog ikke desto mindre den samme fornemmelse som hos James af at være kommet tæt på religiøsitetens (her dog: den kristne udgave i en bestemt kultur på et bestemt tidspunkt) centrale kendetegn.

Disse sammenfattes i den eksperimentelle religionspsykologi i en teori om den »cegte« religiøse oplevelse, som Gruehn et sted karakteriserer på følgende måde:

Im echten religiösen Erlebnis tritt das Gesamt-Ich des Menschen in eine eigentümliche innerliche Verbindung mit dem Gottesgedanken: der Gottesgedanke wird innerlich erlebt, er wird mein Eigentum. D.h. ich denke ihn nicht nur, stelle ihn mir nicht nur vor, sondern ich bin mit meinem ganzen Ich an diesem Gedanken beteiligt, trete völlig für diesen Gedanken ein. Gottesgedanke und Ichfunktion in unlöslicher Verbindung stellen die Eigenart lebendiger Frömmigkeit dar. ${ }^{11}$

Det er ikke vanskeligt at se, at denne angiveligt videnskabelige bestemmelse af den religiøse oplevelse uden større besvær kan relateres til teologiske formuleringer om den troendes eksistentielle tilegnelse af Guds Ord, og Grønbæk er da også gået dette skridt videre, idet han har indført begrebet den kristne grundoplevelse, som er karakteriseret derved, at hjertet i troen griber Guds Ord. ${ }^{12}$

Om end det altså ikke kan nægtes, at den eksperimentelle religionspsykologi har fremdraget vigtige aspekter af den individuelle religiøsitet, må man dog rejse den afgørende indvending imod den, at den i realiteten blot suggererer at have analyseret den religiøse oplevelse - simpelthen fordi grundlæggende begreber som »Gesamt-Ich « (der synes at være et fors $\emptyset \mathrm{g}$ på en »videnskabelig « oversættelse af det religiøse sprogs tale om »hjertet «), »jeg-funktioner og »guds-tanke« i realiteten forbliver ubestemte.

\section{Den individuelle religiøsitet i psykoanallytisk belysning}

Betragter man de seneste årtiers udvikling i religionspsykologien under synsvinklen »teoretisk nytænkning «, må det konstateres, at psykoanalysen i næsten forbløffende grad har været i stand til at levere inspiration til nye og forskningsmæssigt frugtbare problemstillinger. Det må dog samtidig tilføjes, at der gik endog meget lang tid, før det blev muligt bagved den anstødelige religionskritik i Freuds grundtese, „Gud er psykologisk set intet andet end den ophøjede fader-figur«, at få øje på den egentlige pointe $\mathrm{i}$ det psykoanalytiske paradigme, nemlig at udformningen af en persons religiøsitet er determineret af barnets forhold til forældrene, et 


\section{Religionspsykologi som teori}

forhold, som i følge Freud når sit dramatiske klimaks i Oedipus-komplekset. Hermed er det samtidig angivet, at psykoanalysens force - til forskel fra de to ovenfor skitserede positioner - er det genetiske perspektiv, dvs. at kunne levere svar på spørgsmål af typen: Hvorfor udvikles en bestemt persons religiøsitet/gudsforestilling på den og den bestemte måde?

Uanset at denne grundlæggende pointe i den psykoanalytiske synsmåde er blevet fastholdt, er der dog i tidens løb blevet indført en række vidtgående revisioner af Freuds tankegang og argumentation. Meget komprimeret kan disse fremstilles i tre punkter:

1) Trods Freuds berømte dictum: »Wo Es war, soll Ich werden«, har den psykiske jeg-instans ikke desto mindre fået en stedmoderlig behandling $\mathrm{i}$ hans metapsykologiske skrifter. Denne underbelysning af jeget blev der i første omgang rådet bod på med Anna Freuds Das Ich und die Abwehrmechanismen (1936), og senere - fra slutningen af 1950'erne - med Heinz Hartmanns grundlæggelse af en psykoanalytisk jeg-psykologi. Til denne teoretiske nyorientering knytter sig desuden to centrale bidrag til studiet af personlighedsudviklingen: den såkaldte »engelske skoles« teori om objektrelationer (D.W. Winnicott m.fl.), samt Heinz Kohuts narcissismeteori, der bl.a. har fokuseret på udviklingen af selvet.

2) Disse nye indsigter, der gør det muligt at analysere jeg-udviklingen som et dialektisk spil imellem selv- og objekt-repræsentationer, har resulteret $i$ endnu en revision, nemlig en udvidelse af Freuds teori om den psykoseksuelle udvikling (centreret om Oedipus-komplekset) i to retninger: »bagud« forstået på den måde, at kliniske erfaringer har vist, at den såkaldte »spejlings-fase « $\mathrm{i}$ spædbarnets forhold til moderen er af afgørende betydning for udviklingen af en »basic trust « (Erik H. Erikson) som grundlag for senere selv-opfattelse og identitet. Samme Erikson har desuden forlænget Freuds psyko-seksuelle udviklingsteori ud over puberteten, idet han har rykket spørgsmålet om jeg-udvikling og identitets-dannelse ind $\mathrm{i}$ et perspektiv, der omfatter hele individets livscyklus.

3) Tendensen i retning af at betone jeg-funktionerne har også præget udviklingen af psykoanalytisk symbolteori, som især er blevet hjulpet frem af opdagelsen af en hermeneutisk dimension i Freuds terapi og metapsykologi (Habermas; Ricoeur). Uden her at kunne forfølge udviklingen i Freuds symbolforståelse i detaljer kan hans hovedtese formuleres på den måde, at kun det fortrængte har brug for symbolsk fremstilling, sådan som det typisk sker i drømme. Denne tætte forbindelse mellem symbolet og 
det ubevidste er især blevet kritiseret af Alfred Lorenzer, som i en række bøger fra 1970'erne har formuleret en interaktionistisk symbolteori, hvor jegets evne til at kommunikere ved hjælp af symboler står i forgrunden. Synspunktet nærmer sig her en direkte omvending af Freuds, idet fortrængningen forstås som en desymbolisering, en udelukkelse fra kommunikationsfællesskabet, hvorved den syge isoleres i et "privatsprog « præget af ubevidste »klichéer«. Det er ikke formålet her at gå ind i en diskussion af forskellene mellem disse to synspunkter, som naturligvis bl.a har at gøre med forskellige definitioner af symbolbegrebet. Jeg nøjes med at fastholde den pointe, at indsigten i symbolisering som en afgørende jeg-funktion har åbnet for en særdeles frugtbar og perspektivrig dialog med en mere teologisk orienteret interesse i symboler og deres funktion. ${ }^{13}$

De religionspsykologiske implikationer af denne teoretiske udvikling træder særligt klart frem i et af de vigtigste nyere værker i denne tradition, Ana-Maria Rizzutos The Birth of the Living God (1979).$^{14}$ Rizzuto leverer ingen religionsdefinition og understreger, at undersøgelsens sigte er begrænset til analysen af guds-repraesentationens (dvs. individets »private« Gud, sammensat af erfaringsmateriale fra de tidlige relationer til forældrene) opkomst og senere udvikling.

En af bogens mere markante teser går ud på, at ethvert individ i vores kultur udvikler en guds-repræsentation, som blot hos mange skubbes i baggrunden (på samme måde som andre af barnets kreative sider!), hvorfra den dog senere kan bringes til live igen, f.eks. i forbindelse med en eksistentiel krise- eller overgangssituation. I denne tese forbliver det dog uklart, hvorvidt der er tale om indflydelse fra et religiøst miljø (Rizzuto taler ud fra en katolsk baggrund), men under alle omstændigheder bliver det interessant at studere mødet mellem den enkeltes gudsrepræsentation og den »officielle« religions gudsopfattelse.

Rizzutos bog er også karakteristisk ved at være baseret på klinisk arbejde, som jo, når det fungerer efter sin hensigt, dvs. som en stadig vekselvirkning mellem teori og praksis, er psykoanalysens egentlige styrke. Hun fremlægger fire case-studies, hvor forholdet mellem personens livshistorie og gudsrepræesentation belyses på grundlag af både dybde-interviews og udførlige spørgeskemaer. Denne indfaldsvinkel giver et meget stærkt indtryk af, ikke blot hvor forskellig hvert enkelt menneskes »Gud« er, men også - og det er jo ikke det mindst interessante - hvorfor. 


\section{Religionspsykologi som teori}

\section{Socialpsykologiske perspektiver}

Når man som i denne artikel betoner, at religionspsykologiens primære kompetence og opgave vedrører udformningen af en teori om den individuelle religiøsitet, er der altid en risiko for, at det individuelle perspektiv ender med at blive individualistisk. Vil man undgå dette, er det nødvendigt - i det mindste virtuelt - at orientere sig imod de mere socialpsykologiske bidrag til religionspsykologien. ${ }^{15}$

Her som andre steder varierer religionsdefinitionerne, men grundlæggende betragtes religionen som et kulturelt menings- og tydningssystem, som den enkelte internaliserer via den primære og sekundære socialisation. Dermed er det samtidig angivet, at individets adfærd og bevidsthed altid på forhånd er indfældet i den sociale interaktion.

Når det drejer sig om metoder og indfaldsvinkler, er billedet imidlertid broget, selvom der eksempelvis kan findes interessante lighedspunkter imellem Hjalmar Sundéns rolleteori og en religionspsykologisk anvendelse af den såkaldte attributionsteori. ${ }^{16} \mathrm{Jeg}$ mener dog, det er muligt at udpege ét overordnet fællestræk ved de socicalpsykologiske perspektiver, og det er betoningen af begrebet »referenceramme«. Det hermed forbundne synspunkt kan man kort formulere i tesen: Uden religiøs referenceramme, ingen religiøs oplevelse - eller mere konkret: Forudsætningen for at kunne attribuere religiøst eller gå ind i et religiøst rollesystem er, at man er fortrolig med den pågældende religions meningssystem.

Fordelene ved dette synspunkt turde være indlysende, men samtidig kan der peges på mindst to vanskeligheder: a) En regelret socialpsykologisk indfaldsvinkel har svært ved at forklare, hvordan det går til, at personer bliver religiøse i et sækulariseret samfund, hvor den religiøse traditionsformidling stort set er gået tabt. b) Det socialpsykologiske perspektiv kommer let til at fremstå enten som en »bortforklaring « af det religiøse, eller som en overfladisk analyse, der ikke formår at kaste lys over den religiøse oplevelses individuelle dynamik.

\section{Forholdet mellem klassiske og moderne ansatser i religionspsykologien}

Et af de mange spørgsmål, som den forudgående oversigt giver anledning til, vedrører selve forholdet mellem - idealtypisk set - henholdsvis den »klassiske« og »moderne« udgave af religionspsykologien. For man kan næppe undgå at sidde tilbage med det indtryk, at den tidlige religionspsykologi (her i skikkelse af William James) forholder sig både tættere og 
mere nuanceret til det religiøse livs udtryksformer, end tilfældet er i de fleste moderne undersøgelser. Anderledes udtrykt: De klassiske bidrag er tættere på det, jeg har kaldt den religionspsykologiske forsknings primære opgave, nemlig belysningen af den individuelle religiøsitet. Det er derfor heller ikke svært at være enig i følgende vurdering af Spilka, Hood og Gorsuch:

This early period in the psychology of religion provided a framework for understanding religious conversion that remains fruitful even today. If this early research can be faulted on methodological and other grounds, its richness in terms of its extensive individual focus has been largely lost in contemporary psychological concerns. Today, /..../ conversion is likely to be less positively evaluated, and certainly studied with less personal depth. (The Psychology of Religion. An Empirical Approach, 200 ; min kursivering, TN).

Med andre ord: I løbet af religionspsykologiens udvikling er der blevet vendt op og ned på forholdet mellem stærke og svage sider på den måde, at hvor den tidlige forskning var stærk i den indholdsmæssige beskrivelse, men svag i metodisk henseende, er det i dag omvendt. Denne måde at gøre status på rejser det grundlæggende spørgsmål, om det altid og nødvendigvis er sådan, eller om det er muligt så at sige at få »det hele«?

For den første, semi-tragiske mulighed taler bl.a. Løgstrups nærmest polemiske modstilling af »fænomenologi« og »psykologi« som to væsensforskellige indfaldsvinkler. ${ }^{17}$ Forklaringen skal som bekendt søges i hans tese om, at videnskaben (her: psykologien) for i det hele taget at kunne komme i gang med sit forehavende er nødt til at foretage en reduktion af virkeligheden, dvs. at man fokuserer på nærmere bestemte og udvalgte aspekter, hvorimod den fænomenologiske filosofi angiveligt beskriver virkeligheden i den ureducerede skikkelse, hvori den fremtræder for hverdagslivets og dagligsprogets erfaringsverden.

For den anden, utopiserende mulighed taler intet som helst, for så vidt som al vores erfaring belærer os om, at vi aldrig kan få det hele; men måske er det muligt at få mere, end det første enten/eller-alternativ lægger op til? Måske er der sket en fejl-udvikling i religionspsykologien, og måske bygger Løgstrups problemformulering på en i virkeligheden falsk modstilling? Indlysende er det imidlertid, at der de facto sker en form for reduktion i den type moderne religionspsykologi, hvor man ud fra et snævert, operationaliseret religionsbegreb f.eks. vil undersøge relationen mellem »tro på Gud « og antallet af seksual-partnere hos 50 college-studenter. Jeg vil ikke gå så vidt som til at sige, at sådanne undersøgelser er unød- 


\section{Religionspsykologi som teori}

vendige eller ligefrem værdiløse, men ind imellem er det unægtelig svært at undertrykke et »who cares«. I hvert fald er det et problem, hvis vi ender i en situation, hvor religionspsykologi ikke er andet og mere end sådanne fra enhver overordnet refleksion isolerede, empiriske undersøgelser.

Min pointe $\mathrm{i}$ forhold til såvel denne type religionspsykologi som Løgstrups omtalte modstilling er imidlertid, at de begge er fælles om en både fejlagtig og forældet forståelse af forholdet mellem filosofi og enkeltvidenskaber. Begge går de nemlig ud fra, at filosofi og videnskab ikke har noget med hinanden at gøre, ja at de ligefrem har modsatrettede interesser. Som det skulle være fremgået, har denne opfattelse præget psykologiens og religionspsykologiens udvikling, men det bliver den ikke mindre forkert af. Sandheden er jo nemlig, at ingen af parterne kan leve uden den anden: Filosofien kan ikke (længere) løse sine problemer uden at indoptage enkeltvidenskabelige resultater, og omvendt må samfundsvidenskaberne gang på gang konstatere, at filosofisk-normative problemer dukker op midt i de empiriske undersøgelser.

Man kunne også sige det på den måde, at der må skelnes imellem henholdsvis en nødvendig og en unødvendig reduktion. Løgstrup har jo i den forbindelse ret $i$, at det er enhver videnskabelig fremgangsmåde iboende at foretage en række »reduktioner« $\mathrm{i}$ form af den begrænsning af genstandsfelt og indfaldsvinkel, som nu engang altid er nødvendig for at opnå erkendelse. Når han alligevel kommer til at trække grænsen mellem filosofi og videnskab et forkert sted, skyldes det især, at hans »modstander « er en nu gennemskuet og forældet udgave af en i egen selvforståelse objektiv og værdifri, positivistisk videnskab.

Den unødvendige reduktion antager typisk én af to former: Enten den hvor man bevidst eller ubevidst lukker øjnene for de implicerede filosofiske problemer, eller den hvor man ikke udnytter en mulig kobling af filosofi og videnskab, af reflekterede hypoteser og empirisk efterprøvning. Denne unødvendige reduktion er så meget mere trist, netop når det gælder samfundsvidenskaberne, som i følge hele deres anlæg burde gå foran med hensyn til at få teori og empiri til at hænge sammen. Det er da også i dette lys, man skal se Habermas' forkærlighed for de såkaldte »rekonstruktive« videnskaber (f.eks. Lawrence Kohlbergs forening af filosofi og psykologi til en teori om moral-udvikling). ${ }^{18}$ 


\section{Religionspsykologien og den sækulare modernitet}

I forlængelse af det foregående kan det konstateres, at religionspsykologien $\mathrm{i}$ tidens $l ø b$ har undergået en samfundsvidenskabelig opstramning, som ved første øjekast må siges at have givet disciplinen fastere metodisk grund under fødderne. Ved nærmere eftersyn er der dog af mindst to grunde tale om en »mixed blessing «: For det første, fordi den metodiske strømlining i de fleste tilfælde er blevet betalt med et tab af filosofisk refleksion, og for det andet, fordi det har medført en tendens til, at religionspsykologiens særpræg er blevet udvisket til fordel for en tilnærmelse til religionssociologiske synsmåder - en udvikling, der fremtræder særlig klart i den nyere litteratur om omvendelse. ${ }^{19}$

Med en vis ret kan man altså tale om, at religionspsykologien har gennemgået en intern scekulariseringsproces, som naturligvis ikke er uden forbindelse til både forskernes og den omgivende kulturs sækulariseringsgrad. Det viser sig helt konkret deri, at man - stadig sammenlignet med James og hans samtidige - ikke véd, hvad individuel religiøsitet er for noget. Religionspsykologien har i vidt omfang fulgt religionssociologiens tilbøjelighed til at abonnere på et inklusivt, funktionelt religionsbegreb, i følge hvilket snart sagt hvadsomhelst kan være »religion«.

Misforstå mig ikke, - jeg drømmer naturligvis ikke om at bebyrde religionspsykologien med den opgave at fortælle tidens sækulare, pluralistiske og kulturrelativistiske bevidsthed, hvad individuel »religion « »er « for noget; jeg er blot bekymret over, at spørgsmålet end ikke formuleres, og samtidig konstaterer jeg, at dets mangeårige fravær har resulteret $\mathrm{i}$ en indholdsmæssig forarmelse af religionspsykologien.

Vi er hermed fremme ved nødvendigheden af at forstå, hvad der menes med den så ofte udtalte karakteristik af religionspsykologien som en "graensevidenskab«. I forhold til filosofien betyder det, at den skal være åben over for at opdage og overveje de filosofiske problemer (f.eks. spørgsmålet om menneskesyn), selvom den naturligvis hverken kan eller skal besvare dem.

Hvad jeg hermed vil plædere for er, at en »mild « form for normativitet fortsat bør spille en rolle i det religionspsykologiske arbejde; ${ }^{20}$ ikke med det formål at »foreskrive« en bestemt måde at være religiøs på, men simpelthen for at have noget, i forhold til hvilket man kan vurdere det sækulariserede samfunds pluralistiske og ofte noget diffuse religiøsitet. Til det formål er det nok i dag vanskeligere end det var for James at finde »reli- 


\section{Religionspsykologi som teori}

giøse virtuoser«, men en noget mere nærliggende idé ville være, at gøre vores religiøse traditions tekster til genstand for en religionspsykologisk analyse. Særlig oplagt - men ikke desto mindre forsømt - forekommer det at studere de tekster, som direkte ligger til grund for den religiøse praksis, altså salmer, bønner, ja liturgisk sprog i det hele taget. Dette ville samtidig give anledning til at overveje det metodisk set interessante spørgsmål om forholdet mellem religionspsykologiens fremmede (nemlig videnskabelige) perspektiv og dens genstandsfelts selvforståelse. ${ }^{21}$ I forlængelse heraf ville det endvidere være relevant at unders $\emptyset$ ge afstanden mellem på den ene side det liturgiske sprogs selvforståelse og på den anden side gudstjenestedeltagernes oplevelse af samme.

\section{Religionspsykologiens fremtid: henimod en overordnet, teoretisk konvergens?}

Religionspsykologiens faktiske, aktuelle virkelighed er en mangfoldighed af erkendelsesinteresser og indfaldsvinkler, og sådan bør det naturligvis også være, blot med de forbehold, som er anmeldt i det foregående, og her især betydningen af, at der breder sig en fælles forståelse af:

- at religionspsykologien er til for at gøre os klogere på, hvad det vil sige at være »religiøs«, primært i vores egen kultur og religiøse tradition, hvis særpræg dog kun kan vurderes i sammenligning med andre kulturelle og religiøse manifestationer;

- at forpligtetheden på en videnskabelig fremgangsmåde ikke dispenserer fra nødvendigheden af at reflektere filosofiske, religiøse (ja sågar teologiske) og sociologiske problemstillinger.

I lyset af det med jævne mellemrum formulerede behov for en overordnet, religionspsykologisk teori, forekommer det rimeligt, også som korrektiv til urgeringen af forskellen mellem den klassiske og den moderne religionspsykologi, at overveje, hvorvidt de fire positioner, der her er blevet skitseret, er i stand til at supplere hinanden eller ligefrem at kunne forenes. Af hensyn til såvel plads som overskuelighed nøjes jeg her med at anføre følgende punkter:

1) Den psykoanalytiske traditions $\emptyset$ gede betoning af jeg-funktionerne gør det i princippet muligt at bringe den i rapport til retninger, der fors $\emptyset$ ger at belyse jegets og selvets rolle i den religiøse personlighed - her: de to varianter af en »klassisk « religionspsykologi.

2) Psykoanalysens interesse for individets evne til symbolisering åbner for 
en forbindelse til såvel teologiske som sprogfilosofiske overvejelser.

3) Psykoanalysens interesse for driftsskæbner og objektrelationer åbner $i$ princippet for en indoptagelse af socialpsykologiske perspektiver som f.eks. Habermas' Mead-inspirerede begreb om »kommunikativ handlen«. 4) Som Spilka, Hood og Gorsuch har vist, kan man benytte James' grundtanke (at den religiøse oplevelse er løsningen på en forudgående krise eller indre spændingstilstand) som basis for en generel model, der er i stand til at integrere en lang række bidrag til studiet af den religøse oplevelse.

5) En sådan model for den individuelle religiøsitet ville med fordel kunne afprøves på centrale religiøse teksters selvforståelse, og derefter søges koblet til henholdsvis et genetisk og et interaktionistisk (socialpsykologisk) perspektiv. Det sidste muliggøres i øvrigt af, at såvel individuel som kollektiv religiøs praksis kan anskues som en kommunikativ handlen via religiøse symboler.

Kun ved at tænke videre i retning af en sådan mulig, overordnet konvergens, bliver det også muligt at forestille sig en hegelsk »Aufhebung« af de dikotomier, der udgør en så væsentlig del af religionspsykologiens problemer: indre oplevelse versus ydre adfærd; bevidst versus ubevidst; det individuelle versus det sociale - for nu blot endnu engang at minde om nogle af de vigtigste. Sådanne dikotomier eksisterer imidlertid ikke i den religiøse bevidstheds selvforståelse, og alene af den grund vil en reflekteret opblødning være ønskværdig, hvis fremtidens religionspsykologi i højere grad skal kunne leve op til sin oprindelige opgave: Ud fra en teori om den individuelle religiøsitet at levere resultater, indsigter, analyser og beskrivelser, der er i stand til både at udvide og præcisere vores forståelse af homo religiosus.

\section{Noter}

1. Se hertil Stephan Strasser, The Soul in Metaphysical and Empirical Psychology, New York, 1973.

2. For en mere udførlig behandling af det foregående se Hendrika Vande Kemp, »Dangers of Psychologism: The Place of God in Psychology «, Joumal of Psychology and Theology, 14, 1986, 97-109. En kort oversigt over religionspsykologiens metodeproblemer finder man f.eks. hos David A. Flakoll, »A History of Method in the Psychology of Religion (1900-1960)«, Joumal of Psychology and Theology, 4, 1976, 51-62, samt hos H. Newton Malony, »New Methods in the Psychology of Religion«, ibid., 141-151.

3. Bemærk i denne forbindelse, at det, der gør Jung til en interessant »outsider« $i$ moderne psykologi, jo netop er hans utrættelige insisteren på »sjælens virkelighed «, som 


\section{Religionspsykologi som teori}

stiller psykologen over for den opgave at beskrive og fortolke det indre livs kræfter og deres symbolmættede udtryk.

4. Den freudske psykoanalyse har varet fremdraget som eksemplet instar omnium på en uudlignelig spænding imellem en naturvidenskabelig og en hermeneutisk diskurs. På dette grundlag har især Habermas og Ricoeur hævdet, at Freud lå under for en »scientistisk selv-misforståelse «; denne tese kritiseres imidlertid skarpt i Adolf Grünbaums The Foundations of Psychoanalysis, Berkeley 1984, der samtidig rejser alvorlig tvivl om psykoanalysens videnskabsteoretiske soliditet.

5. If. Hilgard, Atkinson og Atkinson, Introduction to Psychology, 7th ed., New York 1979, 12.

6. Det er således betegnende for den etablerede psykologis holdning, at man f.eks. i den omtalte håndbog af Hilgard, Atkinson og Atkinson ikke kan finde begreber som 'religion' og 'religiøsitet' i det ellers omfattende indeks. At forholdet er det samme i næsten alle psykologiske håndbøger, dokumenteres i en interessant artikel af Allan R. Andrews, »Religion, Psychology, and Science: Steps toward a Wider Psychology of Religion«, Joumal of Psychology and Theology, 7, 1979, 31-38.

7. Det er i denne forbindelse karakteristisk, at vigtige impulser til religionspsykologien ikke mindst er kommet fra den vekselvirkning mellem teori og praksis, som finder sted $\mathrm{i}$ klinisk psykologi og psykoterapi, samt i den pastoralpsykologiske bevægelse og i det hele taget i dialogen mellem teologi og psykologi. Jf. hertil tidsskrifter som Pastoral Psychology, Joumal of Religion and Health og Joumal of Psychology and Theology.

8. Jf. William James, The Varieties of Religious Experience, (Fount Paperbacks), Glasgow $1982,50$.

9. Se hertil bl.a. Peter L. Berger, "Some Second Thoughts on Substantive versus Functional Definitions of Religion «, Joumal for the Scientific Study of Religion, 1974, 125-133.

10. Blandt den eksperimentelle religionspsykologis vigtigste arbejder må næunes Girgensohns Der seelische Aufbau des religiösen Erlebens (1921), Gruehns Das Werterlebnis (1925) og Die Frömmigkeit der Gegenwart (1956) samt Grønbæks disputats Om beskrivelsen af religiфse oplevelser (1935). For en mere udførlig behandling, se f.eks. David M. Wulff, "Experimental Introspection and Religious Experience: The Dorpat School of Religious Psychology«, Journal of The History of The Behavioral Sciences, 21, 1985, 131150 .

11. Jf. Werner Gruehn, Die Frömmigkeit der Gegenwart, Münster 1956, 81.

12. Jf. Villiam Grønbæk, Oplevelse og Tro, 1935, hvor »den kristelige Grundoplevelse« bringes på den formel, »at Hjertet gennem Troen griber Guds Ord eller gribes deraf« (s. 37).

Jf. også Grønbæks Psykologiske Tanker og Teorier hos Grundtvig, 1951, hvor der »henvises til mere prægnante udtryk for forholdet mellem ordet og hjertet, udsagn, der vel med rette kan siges at gengive Grundtvigs opfattelse af den kristelige grundoplevelse, og som svarer temmelig nøje til den eksperimentelle religionspsykologis fremstilling af den religiøse grundoplevelse $\ll$ (s. 131).

13. Her tænkes især på Paul Tillich, hvis symbolteori har spillet en afgørende, konstruktiv rolle for dialogen mellem teologi og psykologi, sådan som det f.eks. fremgår af Joachim Scharfenbergs Einführung in die Pastoralpsychologie, 1985.

14. Af andre nyere værker $\mathrm{i}$ den psykoanalytiske tradition skal her blot nævnes: Heinz Müller-Pozzi, Psychologie des Glaubens, München 1975; W. W. Meissner, Psychoanalysis and Religious Experience, 1984, og André Godin, The Psychological Dynamics of Religious Experience, 1985. Blandt de lidt ældre værker må nævnes: A. Vergote, Psychologie religieuse, Paris 1966, og Paul W. Pruyser, A Dynamic Psychology of Religion, New York 1968. 


\section{Troels Nørager}

15. De vigtigste arbejder i denne tradition omfatter bl.a.: M. Argyle og B. Beit-Hallahmi, The Social Psychology of Religion, London 1975, og C. Batson og L. Ventis, The Religious Experience. A Social-Psychological Perspective, Oxford 1982.

16. Aftributionsteorien er bl.a. beskrevet i W. Proudfoot og R. Shaver, »Attribution Theory and the Psychology of Religion«, Joumal for the Scientific Study of Religion, 14, 1975, 317-330. Vedrørende forholdet mellem rolleteori og attributionsteori, se Owe Wikström, "Attribution, Roles and Religion: A Theoretical Analysis of Sundéns Role-Theory of Religion and the Attributional Approach to Religious Experience «, Journal for the Scientific Study of Religion, 26, 1987, 390-401.

17. Jf. artiklen »Fænomenologi og psykologi«, der er blevet optrykt i: K. E. Løgstrup, Solidaritet og karlighed. Essays, Viborg 1987.

18. Jf. hertil bl.a. Jürgen Habermas, Moralbewusstsein und kommunikatives Handeln, Frankfurt a.M. 1983.

19. Dette fremgår bl.a. af den glimrende, kommenterede bibliografi af Lewis R. Rambo, »Current Research on Religious Conversion«, Religious Studies Review, 8, 1982, 146159.

20. Jf. til denne problemstilling f.eks. Robert J. Palma, »The Prospects for a Normative Psychology of Religion: G. W. Allport as a Paradigm «, Joumal of Psychology and Theology, 6, 1978, 110-122.

21. I en interessant artikel af Max Heinrich, "Change of Heart: A Test of Some Widely Held Theories about Religious Conversion«, American Journal of Sociology, 83, 1977, 653-680, ses sociologiens og religionens forklaringer som komplementore, og forfatteren peger på nødvendigheden af at inddrage de religiøse traditioners selvforståelse.

\section{Summary}

"Psychology of Religion as a Theory of Individual Religiosity: Problems, Positions and Perspectives". - The first part of this essay deals with some of the theoretical and methodological problems related to the scientific status of psychology. On this basis, the precarious position of psychology of religion is addressed and the author suggests that the discipline's future is dependent upon realizing the necessity of retuming to the original formulation of the task and purpose of psychology of religion, i.e. the creative investigation of the individual's religion. The second part is a survey of four major positions in the psychology of religion (Wiliam James; experimental and psychoanalytic psychology of religion, and approaches from social psychology) and leads, finally, to a brief discussion of some of the more interesting perspectives: 1) The relation between "classic" and "contemporary" approaches in psychology of religion; 2) the influence of secularization and the complementary relation between the scientific perspective of psychology of religion and the self-understanding of religious traditions, groups and persons; 3) the prospect of a future theoretical convergence in psychology of religion.

\section{Troels Norager}

Adjunkt, cand. theol.

Institut for Praktisk Teologi

Aarhus Universitet 